\title{
Effects of Amino Acid Decarboxylase Genes and pH on the Amine Formation of Enteric Bacteria From Chinese Traditional Fermented Fish (Suan Yu)
}

\begin{abstract}
Qin Yang ${ }^{1,2,3}$, Ju Meng ${ }^{1,2,3}$, Wei Zhang ${ }^{4}$, Lu Liu ${ }^{1,2,3}$, Laping He ${ }^{1,2,3}$, Li Deng ${ }^{1,2,3}$, Xuefeng Zeng ${ }^{1,2,3 *}$ and Chun $\mathrm{Ye}^{1,2,3 *}$
\end{abstract}

'School of Liquor and Food Engineering, Guizhou University, Guiyang, China, ${ }^{2}$ Guizhou Provincial Key Laboratory of Agricultural and Animal Products Storage and Processing, Guiyang, China, ${ }^{3}$ Key Laboratory of Animal Genetics, Breeding and Reproduction in the Plateau Mountainous Region, Ministry of Education, Guiyang, China, ${ }^{4}$ College of Food Science and Engineering, Wuhan Polytechnic University, Wuhan, China

The formation of biogenic amines (BAs) is an important potential risk in Suan yu. This study investigated the amine production abilities of 97 strains of enteric bacteria screened from Suan yu. The genotypic diversity of amino acid decarboxylase and the effect of $\mathrm{pH}$ were explored on 27 strains of high-yield BAs. Results showed that high levels of putrescine, histamine, and cadaverine were produced by the 97 strains. In addition, 27 strains carried odc, speA, speB, adiA, and Idc genes. Thirteen carried hdc gene. Morganella morganii 42C2 produced the highest putrescine content of $880 \mathrm{mg} / \mathrm{L}$ via the ornithine decarboxylase pathway. The highest histamine content was produced by Klebsiella aerogenes 13C2 (1,869 mg/L). The highest cadaverine content was shown by Klebsiella pneumoniae 47C2 (1,821 mg/L). odc, adiA, speB, Idc, and hdc play important roles in the cellular acid stress response. Acid stress caused the growth delay but can increase the contents of putrescine, histamine, and cadaverine. Decarboxylase was strain specific rather than species specific. This study provides a reference for the genotypic diversity of decarboxylase and effect of $\mathrm{pH}$ on the types and abilities of BAs produced by enteric bacteria in Suan yu.

Keywords: biogenic amines (BAs), enteric bacteria, amino acid decarboxylase genes, pH, Suan yu

\section{INTRODUCTION}

Suan yu is a Chinese traditional fermented whole fish snack with a characteristic flavor in ethnic minority areas (Miao and Dong minorities) in Southwest China. Different from other fermented fish products, Suan yu is free of fishy odor and taste, features strong fermentation flavor, retains all the nutritional advantages of fish, and remains stable during storage (Zeng et al., 2013b; Gassem, 2017). However, Suan yu is obtained in traditional workshops. The process of Suan yu making provides an ideal condition for the formation of BAs. On the one hand, the raw material processing is random, unhygienic practices, and substandard manufacturing practice can cause growth of spoilage microorganisms (Gardini et al., 2016; Doeun et al., 2017). On the other hand, during natural fermentation, fermented fish gradually acidifies, protein is degraded, and free amino could be transformed into BAs by microbial decarboxylases (Zeng et al., 2013a; Ishimaru et al., 2019; Xu et al., 2019). Once produced, BAs become difficult to eliminate by high-temperature treatment, 
refrigeration, cooking, or technological treatment ( $\mathrm{Lu}$ et al., 2015; Ozogul et al., 2015; Tofalo et al., 2016). If ingested in large amounts, BA can trigger human health problems leading to hypertension, palpitations, vomiting, flushing, and headaches (Bover-Cid et al., 2014).

Zeng et al. (2013b) reported the chemical and microbial properties of six brands of Suan yu from different locations in China. Enterobacteria were detected, and putrescine, cadaverine, and histamine formed in the six brands. The $\mathrm{pH}$ values of Suan yu range from 4.27 to 5.18. A large number of researchers have reported the formation and accumulation of BAs in fish and fish products due to the presence of decarboxylase-producing microorganisms, especially enteric bacteria (Torido et al., 2014). Morganella morganii, Klebsiella pneumoniae, and Enterobacter aerogenes strains of enteric bacteria from fresh fish show decarboxylase activity and decarboxylates amino acid to the biogenic amine (BA) (Torido et al., 2012; Bjornsdottir-Butler et al., 2010). Some enteric bacteria (E. cloacae, Citrobacter freundii) from fish paste and dried milkfish produce histamine (Hsu et al., 2009; Naila et al., 2011). Escherichia coli, Klebsiella pneumoniae, and Klebsiella oxytoca produced putrescine (Wunderlichová et al., 2013).

Decarboxylation of free amino acids by microorganism decarboxylases produces BAs (Latorremoratalla et al., 2014). The production of decarboxylases is highly correlated with the presence of decarboxylase genes. In enteric bacteria, substantial amounts of putrescine can be formed in two metabolic pathways. In the first pathway, putrescine can be synthesized directly from the decarboxylation of ornithine by ornithine decarboxylase enzyme (odc). In the second pathway, it is produced indirectly from the decarboxylation of arginine by arginine decarboxylase (speA, adiA) via agmatine. Agmatine is subsequently converted to putrescine by agmatinase (speB) (Wunderlichová et al., 2015), cadaverine via lysine decarboxylase $(l d c)$, and histamine via histidine decarboxylase $(h d c)$ (de las Rivas et al., 2006; Bjornsdottir et al., 2009; Wunderlichová et al., 2013).

Environmental factors (i.e., free amino acid, $\mathrm{pH}$, temperature, oxygen supply, $\mathrm{NaCl}$ ) influence the ability of BA-producing species/strains and bacterial growth (Takahashi et al., 2015; Rio et al., 2016). pH is an important environmental factor that influences bacterial growth and amino acid decarboxylase formation and activity (Usheer et al., 2011; Chiara et al., 2014). BAs form in fermented fish during the ripening step, in which a large number of proteins are degraded to form free amino acids, and the $\mathrm{pH}$ decreases gradually. Under the cellular acid stress response, abundant free amino acids could be transformed into BAs by microbial decarboxylases to withstand acidic environments, and decarboxylation increases survival (Álvarez-Ordóñez et al., 2010; Usheer et al., 2011; Chiara et al., 2014). qRT-PCR experiments showed that the $h d c$ and hisRS genes are highly induced under acidic and histidine-rich conditions and that the optimum $\mathrm{pH}$ for the hdc activity of enteric bacteria ranges from 5.0 to 6.5 (Chiara et al., 2014; Bjornsdottir-Butler et al., 2015). The $l d c$ expression of $E$. coli is induced at acidic $\mathrm{pH}$ and at high concentrations of the respective amino acids (Park et al., 2017). In addition, previous reports indicated that the polyamines formed by the arginine decarboxylase biosynthetic speA (constitutive decarboxylases) are significant cellular components and are involved in some processes, including DNA replication, transcription, membrane permeability, protein synthesis, and biofilm formation. Meanwhile, the arginine decarboxylase biodegradative adiA (inducible decarboxylases) is mainly involved in cellular acid stress response and the presence of high-concentration arginine (Álvarez-Ordóñez et al., 2010; Kanjee et al., 2011).

However, limited information is available about the production of BAs by the high production of BAs in enteric bacteria isolated from Suan yu. Therefore, the present work aimed to assess BA production by strains of enteric bacteria from different fermentation stages of Suan yu, detect the genotypic diversity of amino acid decarboxylase by PCR, conduct a phenotypic analysis of the BA production by enteric bacteria, and determine the effect of acid stress on bacterial amineproduction ability by RP-HPLC (Coton et al., 2010; Landete et al., 2011; Wunderlichová et al., 2015). This study can be used as a reference for the genotypic diversity of decarboxylase of BA-producing bacteria and effect of $\mathrm{pH}$ on the types and abilities of BAs produced by enteric bacteria in protein-rich fermented foods.

\section{MATERIALS AND METHODS}

\section{Suan Yu Preparation, Strain Isolation, and Growth Conditions}

Fresh carps (Cyprinus carpio L.) were purchased from a local market (Guiyang, Guizhou, China). Suan yu samples were prepared in accordance with the method described by Zeng et al. (2013b). The samples were withdrawn and analyzed on days 3 , $7,12,18$, and 25 . Each sample $(25 \mathrm{~g})$ was placed in a sterile plastic bag and homogenized with $225 \mathrm{ml}$ of $0.85 \% \mathrm{NaCl}$. The homogenized samples were diluted and then placed in violet red bile glucose agar for enterobacteria growth at $37^{\circ} \mathrm{C}$ for $1-2$ days.

\section{Reference Bacterial Strain}

Biogenic amine-producing bacterial strain was purchased from Shanghai Biology Collection Center (Shanghai, China): the histamine-producing Photobacterium phosphoreum CECT 4192, the cadaverine-producing S. sonnei CECT 457 (ATCC 11060), the putrescine-producing Escherichia coli K-12 substr. MG1655 (NC_000913) (de las Rivas et al., 2005, 2006; Wunderlichová et al., 2013).

\section{Detection of Amine-Forming Ability}

Production of BAs was tested by inoculating isolates (7$9 \log$ CFU ml $\mathrm{ml}^{-1}$ ) directly into tubes containing $10 \mathrm{ml}$ of mixed amino acid decarboxylase media. The medium described by Møller (1954) was used to culture the enteric bacteria. The media were supplemented with L-histidine, L-lysine, Larginine, and L-tyrosine at $0.5 \%$ final concentration and Lornithine monohydrochloride (Solarbio, China) at $0.25 \%$ final 
concentration. Pyridoxal-5-phosphate (Macklin, China) was included in the media (at $0.005 \%$ ).

\section{Biogenic Amine Analysis From Bacterial Cultures by RP-HPLC}

Biogenic amines were extracted from the samples in accordance with the procedures developed by Ben-Gigirey et al. (1998) and Curiel et al. (2011) with a slight modification. Exactly $2 \mathrm{ml}$ of the broth media was centrifuged at $12,000 \times g$ for $10 \mathrm{~min}$, and then $1 \mathrm{ml}$ of the supernatant was extracted with $1 \mathrm{ml}$ of $0.4 \mathrm{M}$ perchloric acid for $30 \mathrm{~min}$. BA derivatization was carried out in accordance with the procedures developed by Ben-Gigirey et al. (1998), Zhai et al. (2012), and Zeng et al. (2013b) with a slight modification. A 1-ml aliquot of the extract or a standard solution was mixed with $200 \mu \mathrm{l}$ of $2 \mathrm{M}$ sodium hydroxide and $300 \mu \mathrm{l}$ of saturated sodium bicarbonate. Under alkaline conditions, $2 \mathrm{ml}$ of dansyl chloride $(10 \mathrm{mg} / \mathrm{ml})$ was mixed with each sample and then incubated for $45 \mathrm{~min}$ at $40^{\circ} \mathrm{C}$. Residual dansyl chloride was removed by adding $100 \mu \mathrm{l}$ of $25 \%$ ammonium hydroxide. The mixture was incubated for $30 \mathrm{~min}$ at room temperature and complemented to $5 \mathrm{ml}$ with acetonitrile. Finally, the supernatant was filtered through $0.2-\mathrm{mm}$-pore-size filters prior to RP-HPLC analysis (Agilent 1260; United States). Liquid chromatographic separations were performed using Zorbax SBC18 (4.6 $\times 250 \mathrm{~mm})$. Mobile phases consisted of acetonitrile (A) and water (B). The column temperature and flow rate were set at $35^{\circ} \mathrm{C}$ and $1 \mathrm{ml} \mathrm{min}^{-1}$, respectively. The UV detection wave length was $254 \mathrm{~nm}$. The gradient program is shown in Table 1.

\section{DNA Extraction and Strain Identification}

Total DNA was extracted from bacterial cultures grown to stationary phase using $1 \mathrm{ml}$ of the cultures with the TIANamp Bacteria DNA Kit (TianGen, China) in accordance with the manufacturer's instructions and stored frozen at $-20^{\circ} \mathrm{C}$ until further analysis.

The 16S rDNA gene PCR amplifications of extracted DNA were performed with the following primers: $27 \mathrm{~F}$ (5'-AGAGTTTGATCCTGGCTCAG-3'); 1492R (5'-GGTT ACCTTGTTACGACTT-3'). PCR was performed in a $25-\mu 1$ amplification reaction mixture containing $2.5 \mu \mathrm{l}$ of template DNA, $12.5 \mu \mathrm{l}$ of TaqpMIX (Sangon Biotech, China), and $0.4 \mu \mathrm{M}$ of each primer. The amplification program was as follows: $5 \mathrm{~min}$ for enzyme activation at $94^{\circ} \mathrm{C}$; followed by 35 cycles of $1 \mathrm{~min}$ at $94^{\circ} \mathrm{C}, 1 \mathrm{~min}$ at $55^{\circ} \mathrm{C}$, and $2 \mathrm{~min}$ at $72^{\circ} \mathrm{C}$; and a final extension

TABLE 1 | RP-HPLC elution program for the BAs analysis.

\begin{tabular}{lcc}
\hline Time (min) & Acetonitrile (\%) & $\mathbf{H}_{\mathbf{2}} \mathbf{O}(\%)$ \\
\hline 0 & 60 & 40 \\
15 & 75 & 25 \\
22 & 85 & 15 \\
25 & 90 & 10 \\
28 & 90 & 10 \\
35 & 60 & 40
\end{tabular}

step of $10 \mathrm{~min}$ at $72^{\circ} \mathrm{C}$ (Chen et al., 2010). BLAST analysis was conducted to confirm the bacterial species.

\section{Detection of Amino Acid Decarboxylase Genes in the Biogenic Amine-Producer Strains}

DNAs from 27 strains were subjected to PCR amplification to detect the presence of amino acid decarboxylase genes. The primer pairs 106/107, PUT1-F/PUT1-R, and CAD1-F/CAD1$\mathrm{R}$ were used to detect the $h d c$, odc, and $l d c$ gene fragments, respectively (de las Rivas et al., 2005, 2006). The specific primers adc5F/adc5R, adiA3F/adiA3R, and agm4F/agm4R were used to detect the speA, adiA, and speB gene fragments, respectively (Wunderlichová et al., 2013). The primer sequences are listed in Table 2. All primers were synthesized by Sangon Biotech (China). PCR reaction was performed in a $20-\mu 1$ amplification reaction mixture containing $2 \mu \mathrm{l}$ of template DNA, $10 \mu \mathrm{M}$ of each primer, $20 \mathrm{mM}$ Tris- $\mathrm{HCl}$ ( $\mathrm{pH} 8.0$ ), $50 \mathrm{mM} \mathrm{KCl,} 2.5 \mathrm{mM} \mathrm{MgCl}_{2}$, $200 \mu \mathrm{M}$ of each deoxynucleoside triphosphate, and $0.5 \mathrm{U}$ of DNA polymerase (Solarbio, China). The amplification programs are listed in Table 3. The PCR products were separated on a $2 \%$ agarose gel in $1 \times$ TAE (Tris-acetate/EDTA), stained with GenGreen, and then visualized under a UV lamp (Universal Hood II, Biorad).

\section{BA Production From Different Amino Acid Media}

Phenotypic analysis of the 27 strains was conducted by adding different substrates. The isolates were cultivated in differential amino acid decarboxylase media as described in the Detection of Amine-Forming Ability section, at $37^{\circ} \mathrm{C}$ for $48 \mathrm{~h}$. BA analysis from bacterial cultures was performed by RP-HPLC.

\section{BA Production From Different pH Values}

The effect of acid stress on bacterial amine-forming ability was analyzed. Isolates were cultivated in mix-amino acid decarboxylase media as described in "Detection of AmineForming Ability" section, at $37^{\circ} \mathrm{C}$ for $48 \mathrm{~h}$. The $\mathrm{pH}$ of the media was adjusted to a range of values $(\mathrm{pH} 4.50,5.00,6.00$, and 6.70) by adding disodium hydrogen phosphate-citric acid. BA analysis from bacterial cultures was performed by RP-HPLC.

\section{Determination of pH and Cell Turbidity}

Isolates were cultivated in mix-amino acid decarboxylase media as described in "Detection of Amine-Forming Ability" section. The isolates were grown at $37^{\circ} \mathrm{C}$ for $0,4,8,12,24,36$, and $48 \mathrm{~h}$. Then, the $600-\mathrm{nm}$ absorbance and $\mathrm{pH}$ of the solution were determined with a spectrophotometer $(721 \mathrm{G}$, INESA) and a $\mathrm{pH}$ meter (PHS-3E, INESA), respectively.

\section{Statistical Analysis}

Data were processed by analysis of generalized linear model. All statistical procedures were computed using SPSS 17.0. 
TABLE 2 | Primers used for the PCR targeting BA-production associated genes.

\begin{tabular}{|c|c|c|c|c|}
\hline Primer & Sequence $\left(5^{\prime}\right.$ to $\left.3^{\prime}\right)$ & Product (bp) & Target element & References \\
\hline \multirow[t]{2}{*}{ adc5F/adc5R } & CAAYTTCTCGSTGTTCCAG & 282 & Arginine decarboxylase-biosynthetic (speA) gene & Wunderlichová et al. (2013) \\
\hline & TCRCCRAACAGGTTGTGC & & & \\
\hline \multirow[t]{2}{*}{ adiA3F/adiA3R } & TKCCAASCCGYAACCG & 548 & Arginine decarboxylase-biodegradative (adiA) gene & Wunderlichová et al. (2013) \\
\hline & AACMGCTTCRTCRATCAC & & & \\
\hline \multirow[t]{2}{*}{ agm4F/agm4R } & TGAACGTCGTGGACTGCGG & 355 & Agmatinase (speB) gene & Wunderlichová et al. (2013) \\
\hline & GCRTCCAGCACGGTAAAGC & & & \\
\hline \multirow[t]{2}{*}{ PUT1-F/PUT1-R } & TWYMAYGCNGAYAARACNTAYYYTGT & 1440 & Ornithine decarboxylase (odc) gene & de las Rivas et al. (2006) \\
\hline & ACRCANAGNACNCCNGGNGGRTANGG & & & \\
\hline \multirow[t]{2}{*}{ CAD1-F/CAD-R } & TTYGAYWCNGCNTGGGTNCCNTAYAC & 1098 & Lysine decarboxylase (Idc) gene & de las Rivas et al. (2006) \\
\hline & CCRTGDATRTCNGTYTCRAANCCNGG & & & \\
\hline \multirow[t]{2}{*}{$106 / 107$} & AAYTCNTTYGAYTTYGARAARGARG & 534 & Histamine decaboxylase $(h d c)$ gene & de las Rivas et al. (2005) \\
\hline & ATNGGNGANCCDATCATYTTRTGNCC & & & \\
\hline
\end{tabular}

TABLE 3 | The amplification program using the primer pairs described in Table 2.

\begin{tabular}{|c|c|c|}
\hline Primer & Amplification program & References \\
\hline adc5F/adc5R & $\begin{array}{l}94^{\circ} \mathrm{C} 5 \mathrm{~min} ; 2 \text { cycles of } 94^{\circ} \mathrm{C} 45 \mathrm{~s}, 62^{\circ} \mathrm{C} 1 \mathrm{~min}, 72^{\circ} \mathrm{C} 1 \mathrm{~min} \text {; followed by } 20 \text { cycles, when } \\
\text { annealing temperature was decreased by } 0.5^{\circ} \mathrm{C} \text { in every other cycle: } 94^{\circ} \mathrm{C} 45 \mathrm{~s} \text {, annealing } \\
\text { from } 61 \text { to } 52^{\circ} \mathrm{C} 1 \mathrm{~min}, 72^{\circ} \mathrm{C} 1 \mathrm{~min} ; 10 \text { cycles of } 94^{\circ} \mathrm{C} 45 \mathrm{~s}, 52^{\circ} \mathrm{C} 1 \mathrm{~min}, 72^{\circ} \mathrm{C} 1 \text { min with a } \\
\text { final extension at } 72^{\circ} \mathrm{C} \text { for } 10 \mathrm{~min} \text {. }\end{array}$ & Wunderlichová et al. (2013) \\
\hline agm4F/agm4R & $\begin{array}{l}94^{\circ} \mathrm{C} 5 \mathrm{~min} ; 2 \text { cycles of } 94^{\circ} \mathrm{C} 45 \mathrm{~s}, 62^{\circ} \mathrm{C} 1 \mathrm{~min}, 72^{\circ} \mathrm{C} 1 \mathrm{~min} \text {; followed by } 20 \text { cycles, when } \\
\text { annealing temperature was decreased by } 0.5^{\circ} \mathrm{C} \text { in every other cycle: } 94^{\circ} \mathrm{C} 45 \mathrm{~s} \text {, annealing } \\
\text { from } 61 \text { to } 52^{\circ} \mathrm{C} 1 \mathrm{~min}, 72^{\circ} \mathrm{C} 1 \mathrm{~min} ; 10 \text { cycles of } 94^{\circ} \mathrm{C} 45 \mathrm{~s}, 52^{\circ} \mathrm{C} 1 \mathrm{~min}, 72^{\circ} \mathrm{C} 1 \text { min with a } \\
\text { final extension at } 72^{\circ} \mathrm{C} \text { for } 10 \mathrm{~min} \text {. }\end{array}$ & Wunderlichová et al. (2013) \\
\hline adiA3F/adiA3R & $\begin{array}{l}94^{\circ} \mathrm{C} 5 \mathrm{~min} ; 2 \text { cycles of } 94^{\circ} \mathrm{C} 45 \mathrm{~s}, 62^{\circ} \mathrm{C} 1 \mathrm{~min}, 72^{\circ} \mathrm{C} 1 \mathrm{~min} \text {; followed by } 30 \text { cycles, when } \\
\text { annealing temperature was decreased by } 0.5^{\circ} \mathrm{C} \text { in every other cycle: } 94^{\circ} \mathrm{C} 45 \mathrm{~s} \text {, annealing } \\
\text { from } 61 \text { to } 47^{\circ} \mathrm{C} 1 \mathrm{~min}, 72^{\circ} \mathrm{C} 1 \mathrm{~min} ; 3 \text { cycles of } 94^{\circ} \mathrm{C} 45 \mathrm{~s}, 47^{\circ} \mathrm{C} 1 \mathrm{~min}, 72^{\circ} \mathrm{C} 1 \text { min with a } \\
\text { final extension at } 72^{\circ} \mathrm{C} \text { for } 10 \mathrm{~min} \text {. }\end{array}$ & Wunderlichová et al. (2013) \\
\hline PUT1-F/PUT1-R & $\begin{array}{l}95^{\circ} \mathrm{C} 5 \mathrm{~min}, 25 \text { cycles of } 95^{\circ} \mathrm{C} 45 \mathrm{~s}, 55^{\circ} \mathrm{C} 1 \mathrm{~min}, 72^{\circ} \mathrm{C} 2 \text { min with a final extension at } 72^{\circ} \mathrm{C} \\
\text { for } 10 \mathrm{~min} \text {. }\end{array}$ & de las Rivas et al. (2006) \\
\hline CAD1-F/CAD-R & $\begin{array}{l}95^{\circ} \mathrm{C} 5 \mathrm{~min}, 25 \text { cycles of } 95^{\circ} \mathrm{C} 45 \mathrm{~s}, 55^{\circ} \mathrm{C} 1 \mathrm{~min}, 72^{\circ} \mathrm{C} 2 \mathrm{~min} \text { with a final extension at } 72^{\circ} \mathrm{C} \\
\text { for } 10 \mathrm{~min} .\end{array}$ & de las Rivas et al. (2006) \\
\hline $106 / 107$ & $\begin{array}{l}95^{\circ} \mathrm{C} 5 \mathrm{~min}, 25 \text { cycles of } 95^{\circ} \mathrm{C} 45 \mathrm{~s}, 54^{\circ} \mathrm{C} 1 \mathrm{~min}, 72^{\circ} \mathrm{C} 1 \mathrm{~min} \text { with a final extension at } 72^{\circ} \mathrm{C} \\
\text { for } 10 \mathrm{~min} \text {. }\end{array}$ & de las Rivas et al. (2005) \\
\hline
\end{tabular}

\section{RESULTS AND DISCUSSION}

\section{Isolation of Strains and Determination of Potential BA Production}

A total of 97 isolates were collected from Suan yu. Table 4 shows the BA content and distribution of types in 97 strains of enteric bacteria. The table shows that 97 strains were

TABLE 4 | The BAs content and distribution of types in 97 strains of enteric bacteria.

\begin{tabular}{lccc}
\hline BAs content $(\mathbf{m g} / \mathbf{L})$ & Histamine & Putrescine & Cadaverine \\
\hline$\geq 900$ & 2 & 32 & 0 \\
$500 \leq x<900$ & 5 & 47 & 0 \\
$100 \leq x<500$ & 40 & 9 & 16 \\
$x<100$ & 50 & 9 & 81 \\
$N$ & 97 & 97 & 97 \\
\hline
\end{tabular}

$x$, biogenic amines content; $N$, numbers. divided into four grades according to their ability to produce amines. Enteric bacteria produced particularly high amounts of putrescine, followed by histamine and cadaverine. About $33.0 \%(32 / 97)$ of the strains produced more than $900 \mathrm{mg} / \mathrm{L}$ of putrescine. The percentage of putrescine content between 500 and $900 \mathrm{mg} / \mathrm{L}$ was $48.5 \%$ (47/97). Meanwhile, $2.1 \%$ (2/97) of the strains produced more than $900 \mathrm{mg} / \mathrm{L}$ of histamine. The percentage of histamine content between 500 and $900 \mathrm{mg} / \mathrm{L}$ was $5.2 \%$ (5/97). The content of histamine was between 100 and $500 \mathrm{mg} / \mathrm{L}$, accounting for $41.2 \%$ (40/97). However, no strain produced cadaverine content higher than $500 \mathrm{mg} / \mathrm{L}$. The percentage of cadaverine content between 100 and $500 \mathrm{mg} / \mathrm{L}$ was $16.5 \%(16 / 97)$, and $83.5 \%(81 / 97)$ of the strains were below $100 \mathrm{mg} / \mathrm{L}$. As expected, the enteric bacteria detected were dominantly putrescine, histamine, and cadaverine producers (Bjornsdottir et al., 2009; Torido et al., 2012). Similarly, Kim et al. (2009) found that 23 strains of Enterobacter aerogenes produce large numbers of putrescine, histamine, and cadaverine, and 33 strains of two Enterobacter spp. produce abundant putrescine and cadaverine but less histamine. In this work, none of the tested 
strains produced tyramine under the present assay conditions. Our obtained results agree with previous studies by de las Rivas et al. (2006), Ladero et al. (2012), and Tittarelli et al. (2019). The results described above indicate that the types and abilities of BAs produced by strains of enteric bacteria in Suan yu were different. The reasons for these differences are species and strain specific, diversity of amino acid decarboxylase genes, and effects of environmental factors (ripening temperature, $\mathrm{pH}, \mathrm{NaCl}$, oxygen, Aw). In particular, $\mathrm{pH}$ is one of the most important environmental factors (Coton et al., 2010; Chiara et al., 2014; Ozogul et al., 2015).

\section{DNA Extraction and Strain Identification}

Twenty-seven strains of high-yield putrescine, histamine, and cadaverine were selected from 97 strains for follow-up study. The 16S rDNA of 27 strains was amplified with the universal primers 27F/1492R, and these sequences were analyzed with the BLAST (NCBI). The results are listed in Table 5. Strains were assigned to the different species: two strains of Enterobacter asburiae, two strains of Klebsiella aerogenes, three strains of Klebsiella oxytoca, one strain of Klebsiella pneumoniae, five strains of Enterobacter hormaechei, three strains of Enterobacter ludwigii, seven strains of Morganella morganii, one strain of Citrobacter youngae, two strains of Enterobacter cloacae, and one strain of Enterobacter sp.

\section{Genotypic Diversity of BA Production by Enteric Bacteria}

The primer pair PUT1-F/PUT1-R was used to detect the odc gene; all the 27 strains produced amplicons of the expected sized 1,440 bp (Figure 1F). Similar results were previously observed by de las Rivas et al. (2006), who found that some strains (E. coli MG 1655, M. morganii CECT 173T, Lactobacillus sp. 30a, Serratia liquefaciens IFI-65, and Oenococcus oeni RM83) contain the odc gene. Moreover, the presence of the corresponding speA and adiA genes was demonstrated by PCR assay with adc5F/adc5R and adiA3F/adiA3R primers, which amplified fragments of 282 and 548 bp, respectively (Figures 1C,D). A 355-bp partial speB gene fragment was amplified with the primer set agm4F/agm $4 \mathrm{R}$ to detect the agmatinase gene (Figure 1E). In this work, all tested strains carried $s p e A, s p e B$, and adiA genes. The obtained results were in agreement with the findings of Wunderlichová et al. (2013), who described primers adc5F/adc5R, adiA3F/adiA3R, and agm4F/agm $4 \mathrm{R}$ that amplify corresponding fragments of the $s p e A$, adi $A$, and $s p e B$ genes in a high number of putrescineproducing strains.

TABLE 5 | Identified bacteria of twenty-seven strains of high-yield BAs isolated from Suan yu by $16 S$ rDNA.

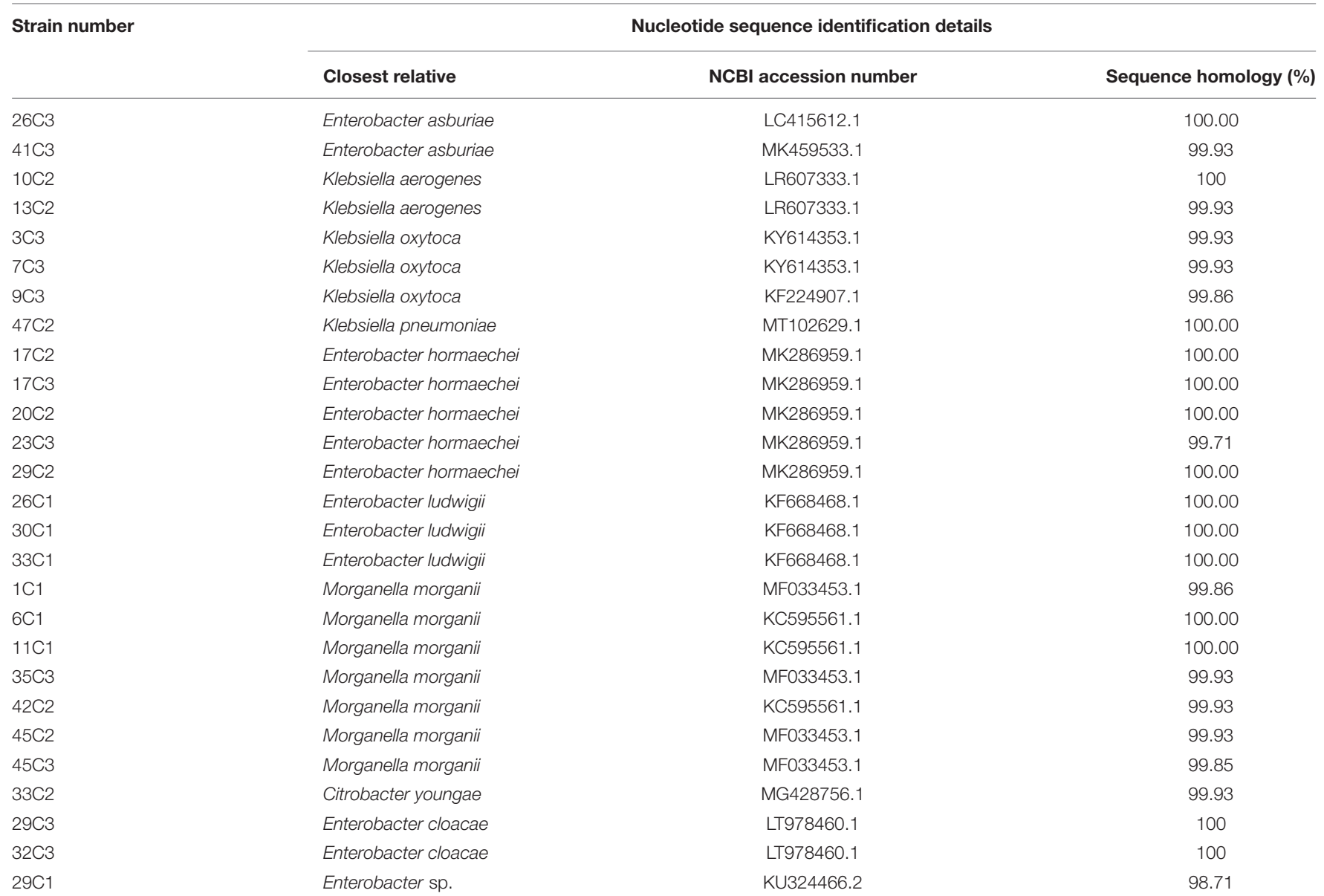


A

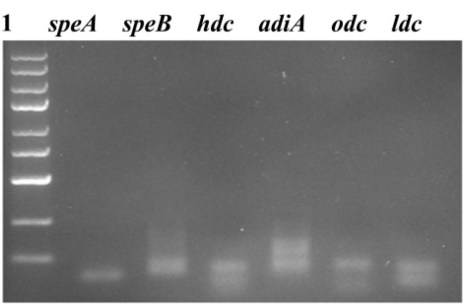

C

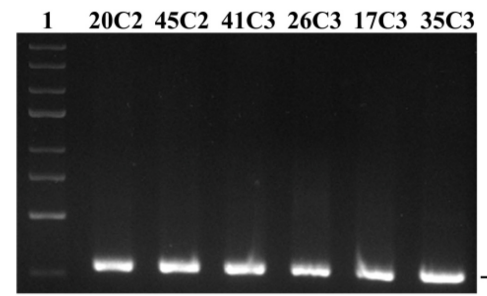

E

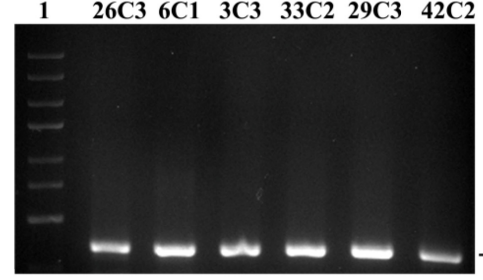

G

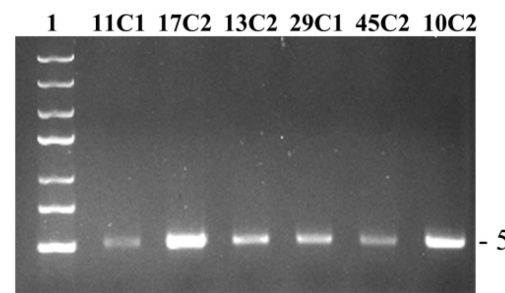

B

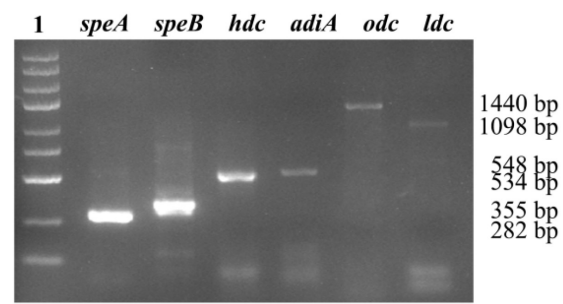

D

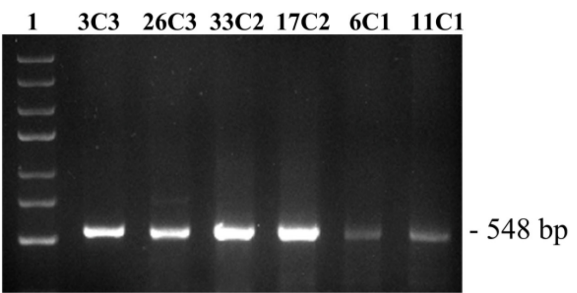

F

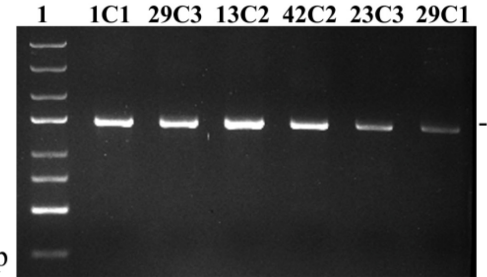

$-1440 b p$

H

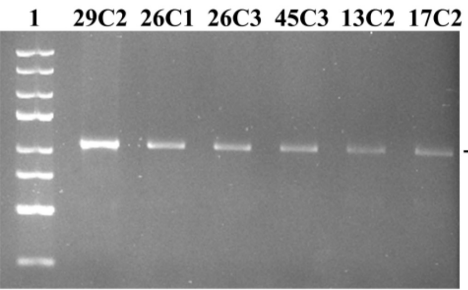

$1098 \mathrm{bp}$

FIGURE 1 | To detect the speA, adiA, speB, odc, hdc, ldc genes by PCR. (A) Negative control. (B) Positive control. (C) speA gene fragment. (D) adiA gene fragment. (E) speB gene fragment. (F) odc gene fragment. (G) hdc gene fragment. (H) Idc gene fragment. Lane 1, 5000 bp DNA ladder; lanes 2-7, PCR products by DNA from part of 27 strains.

The primer pair 106/107 was used to detect the $h d c$ gene. Thirteen strains produced amplicons of the expected size of $534 \mathrm{bp}$ (Figure 1G). Our obtained results agree with the previous study by de las Rivas et al. (2005) who amplified a 534-bp fragment of the $h d c$ gene in $K$. planticola CECT 843 and M. morganii CECT 173. Moreover, the primer couple CAD1-F/CAD1-R was used to detect the $l d c$ gene wherein PCR products were $1,098 \mathrm{bp}$. In this work, all tested strains carried the $l d c$ gene (Figure $\mathbf{1 H}$ ). Similar results were previously observed by de las Rivas et al. (2006), who detected the ldc gene of Gram-negative bacteria by CAD1F/CAD1-R. Curiel et al. (2011) investigated the BA genes of Enterobacteria isolated from fresh sausage packages, indicating that a large number of Enterobacteria species are cadaverine-producer strains possessing the ldc gene. The PCR reaction containing all six primer pairs was validated on known BA-producing represented by three strains (Section 2.2). PCR negative control without DNA (Figure 1A). PCR products by DNA from Photobacterium phosphoreum CECT $4192(h d c)$, S. sonnei CECT 457 (odc), Escherichia coli K-12 substr. MG1655 (speA, speB, adiA) (Figure 1B, positive control).

\section{Phenotypic Analysis for BA Production by Enteric Bacteria}

Phenotypic analysis of the 27 strains was conducted by adding different substrates, and the correlation between the genotypic and phenotypic data was explored. As shown in Figure 2, BAs were formed by the decarboxylation of the corresponding amino acids and amino acid precursors, and the phenotypic and genotypic data coincided. The results show that the phenotypic and genotypic data coincided.

The 27 tested strains were putrescine positive as determined by RP-HPLC in medium supplemented with L-ornithine hydrochloride or L-arginine. In the two metabolic pathways of putrescine production, the phenotypic and genotypic data coincided in 27 strains tested. M. morganii strain $42 \mathrm{C} 2$ produced the highest content of putrescine in the medium supplemented with L-ornithine hydrochloride $(880 \mathrm{mg} / \mathrm{L})$, 


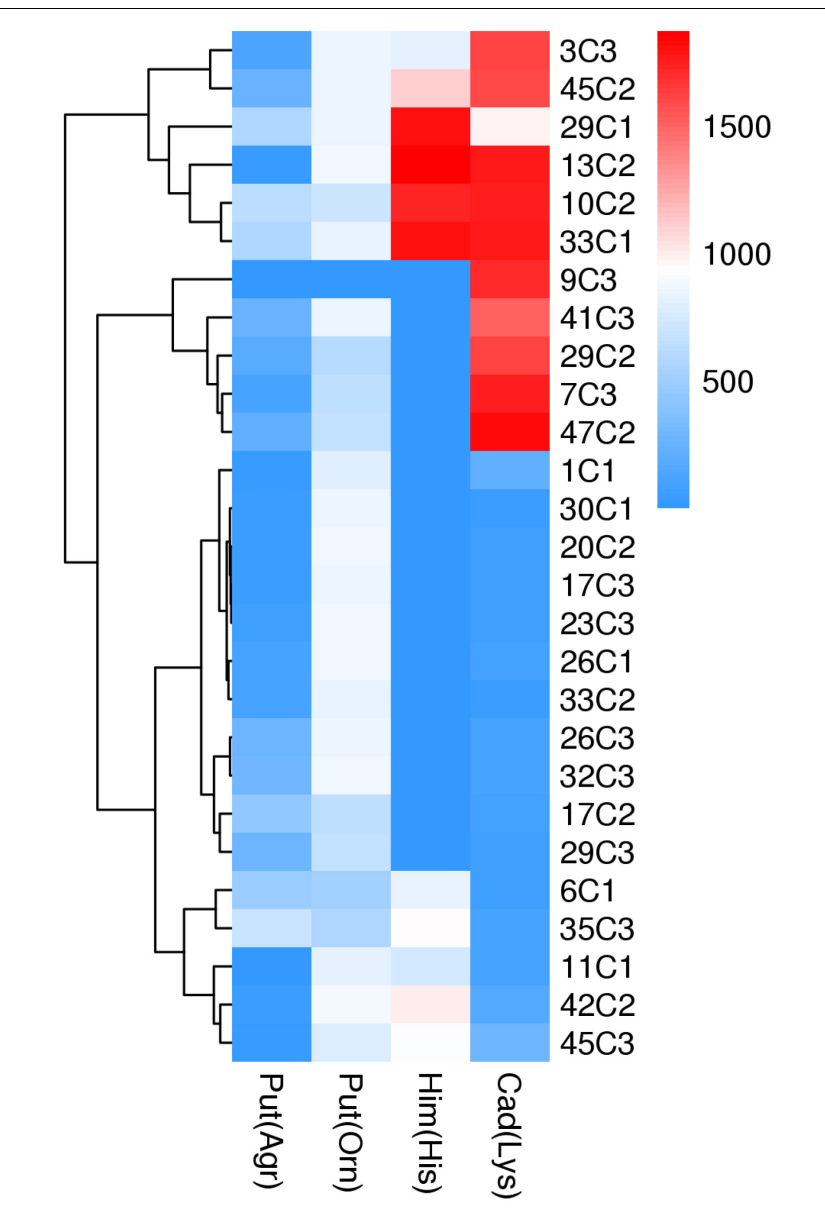

FIGURE 2 | BA production from different amino acid as substrate by enteric bacteria. BA: histamine (Him), putrescine (Put), cadaverine (Cad). Arginine (Arg), ornithine (Om), histidine (His), lysine (Lys).

followed by E. hormaechei 20C2 (873 mg/L), and then K. aerogenes $13 \mathrm{C} 2(871 \mathrm{mg} / \mathrm{L})$. M. morganii $35 \mathrm{C} 3$ produced the highest content of putrescine in the medium supplemented with L-arginine $(681 \mathrm{mg} / \mathrm{L})$.

Thirteen of the 27 tested strains were histamine positive as determined by phenotypic analysis. In addition, 37.0\% (10/27) of the strains produced more than $800 \mathrm{mg} / \mathrm{L}$ of histamine. The highest histamine formation was shown by $K$. aerogenes $13 \mathrm{C} 2$ (1,869 mg/L), followed by Enterobacter sp. 29C1 (1,812 mg/L), and then E. ludwigii strain 33C1 (1,803 mg/L). The 27 tested strains were cadaverine positive as determined by RP-HPLC in medium supplemented with L-lysine, and the phenotypic and genotypic data coincided. K. pneumoniae 47C2 produced the largest amount of cadaverine $(1,821 \mathrm{mg} / \mathrm{L})$, followed by E. ludwigii $33 \mathrm{C} 1(1,765 \mathrm{mg} / \mathrm{L})$, and then $K$. aerogenes $13 \mathrm{C} 2$ $(1,771 \mathrm{mg} / \mathrm{L})$. The cadaverine content of the other strains ranged from 50 to $276 \mathrm{mg} / \mathrm{L}$.

Notably, K. aerogenes 13C2 produced particularly high amounts of putrescine, histamine, and cadaverine. In addition, limited information exists regarding the formation of BAs by $K$. aerogenes isolated from fish and fish products.

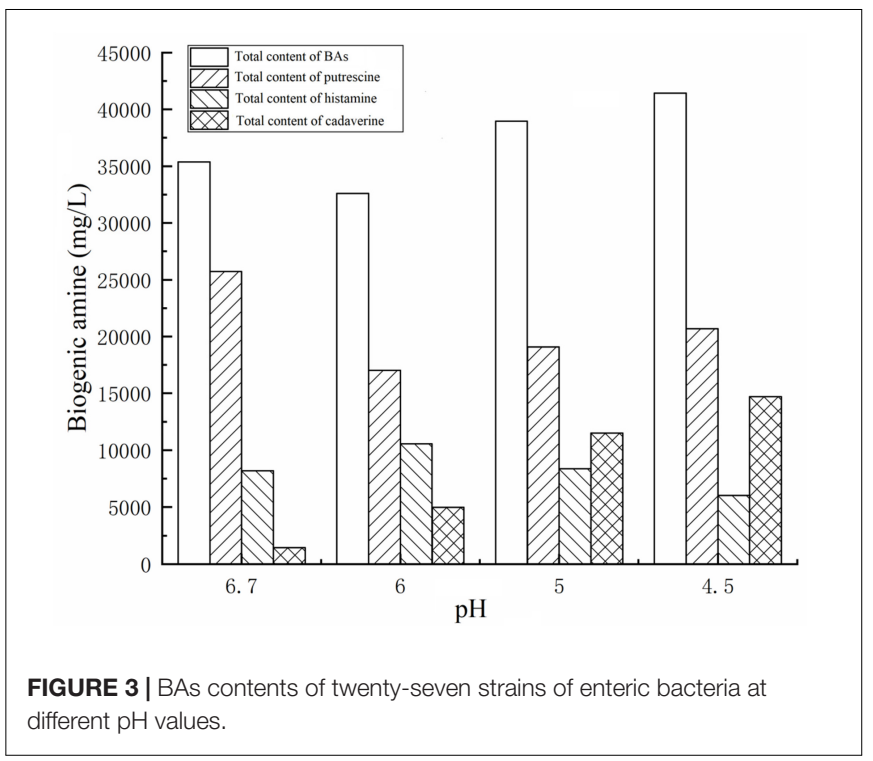

\section{Effects of Different pH Values on the Biogenic Amine Contents and Types Effects of Different pH Values on the Total BA Content of the 27 Strains}

In the present work, to understand the effect of different $\mathrm{pH}$ values on BA production by the 27 strains under mixed substrates, we calculated the total BA content of the 27 strains. As the $\mathrm{pH}$ decreased from 6.70 to 4.50 , the total content of BAs of the 27 strains reached the maximum at $\mathrm{pH} 4.50$ and the lowest at pH 6 (Figure 3). However, the content of BAs decreased sharply at $\mathrm{pH} 4$ because high acid inhibited the growth of enteric bacteria, thus inhibiting the production of BAs (data not shown).

\section{Effects of Different pH Values on the Amines Produced by 27 Strains}

We also calculated the total contents of putrescine, histamine, and cadaverine, respectively (Figure 3), showing the amines produced by each strain (Figures 4A-C). As shown in Figures 3, 4A-C, the different $\mathrm{pH}$ levels affected the BA-producing abilities of the 27 strains in a strain-dependent rather than species-specific manner. These results were in agreement with the findings of Coton et al. (2010) and Ozogul et al. (2015). The cooperation of various amino acid decarboxylase pathways under acid stress and the effect of $\mathrm{pH}$ on the activity of amino acid decarboxylase (Table 6 and Figures 2-4, 6).

\section{Effect of different $p H$ levels on putrescine content}

As shown in Figures 3, 4A, pH considerably affected the putrescine-producing ability of the tested bacteria $(P<0.01)$. As the $\mathrm{pH}$ decreased from 6.70 to 4.50 , the total amount of putrescine of the 27 strains reached the maximum at $\mathrm{pH} 6.7$ and the lowest at pH 6.00 (Figure 3). When the $\mathrm{pH}$ dropped to 5.00 and 4.50 , the total content of putrescine increased but did not exceed the total content of putrescine at $\mathrm{pH}$ 6.70. This result 


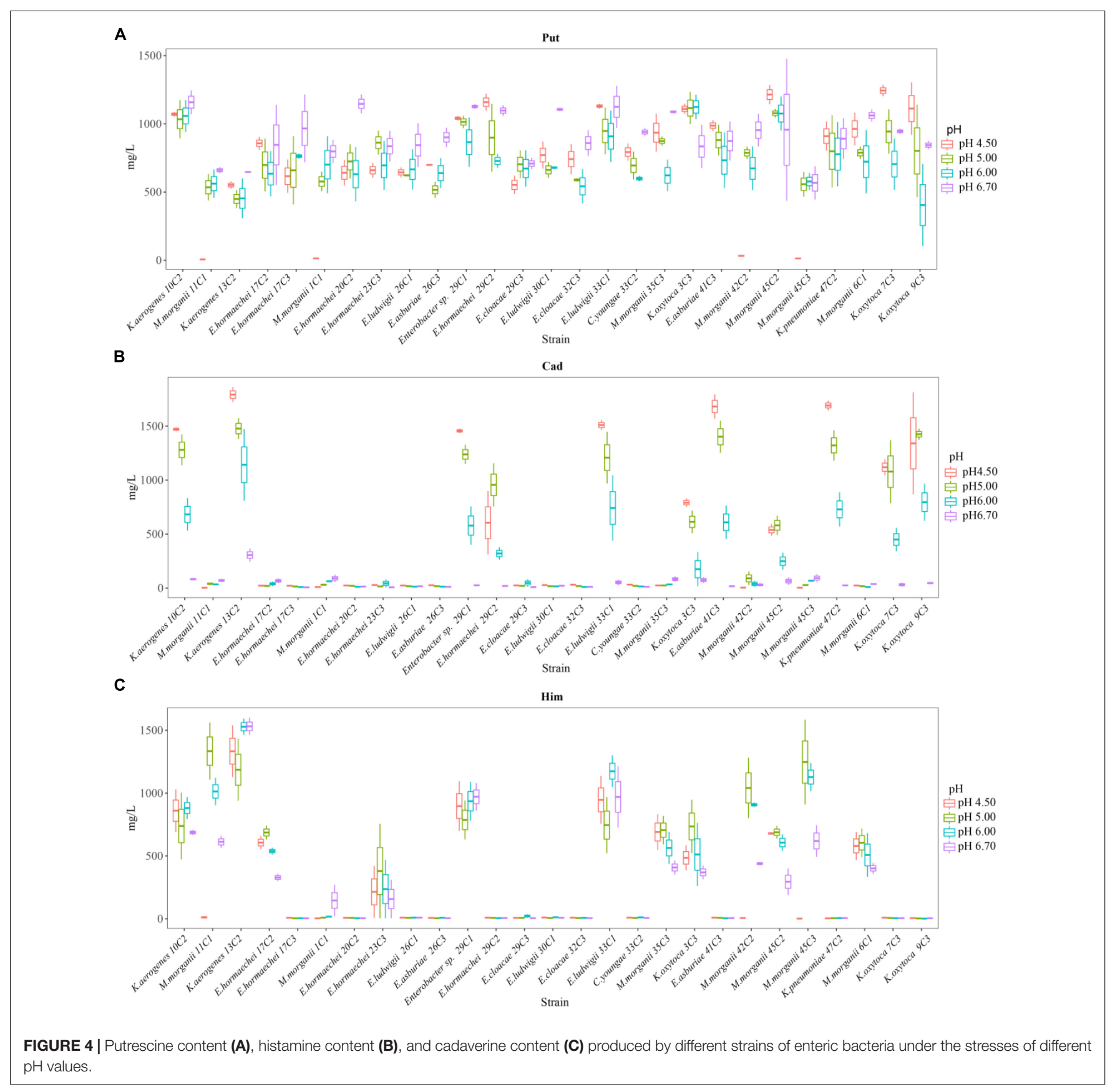

indicates that the optimum $\mathrm{pH}$ for putrescine production is 6.70 (Figures 2, 3, 4A). The putrescine production of $M$. morganii $42 \mathrm{C} 2,11 \mathrm{C} 1,1 \mathrm{C} 1$, and $45 \mathrm{C} 3$ were $\mathrm{ND}$ at $\mathrm{pH} 4.50$ because the high acidity inhibited their growth. The highest putrescine content was produced by M. morganii $45 \mathrm{C} 2(1,478 \mathrm{mg} / \mathrm{L})$ at $\mathrm{pH} 6.7$, followed by E. hormaechei 20C2 (1,215 mg/L) (Figure 4A).

The content of putrescine was the highest at $\mathrm{pH} 6.70$ (Figure 4A). At this $\mathrm{pH}$, the combination of adiA and odc consumed arginine and ornithine, respectively, in the environment to produce a large amount of putrescine, and the contribution of ornithine decarboxylase $(o d c)$ to the production of putrescine was greater than that of arginine decarboxylase
adiA. The following results illustrate the above inferences. At $\mathrm{pH}$ 6.70, the total amount of putrescine obtained by adding two types of single substrates was basically the same as that obtained by mixing substrates (Figures 2, 4A). For putrescine production under single substrate (Figure 2), when the $\mathrm{pH}$ was 6.70 , the amount of putrescine produced by adding Lornithine hydrochloride as the substrate was greater than that of L-arginine as the substrate. Usheer et al. (2011) have reported that the optimum $\mathrm{pH}$ for odc is 7.00. In addition, adiA alone has a peak activity at $\mathrm{pH}$ 5.00. The activity of adiA drops off very dramatically at $\mathrm{pH}$ values higher than 6.00 and lower than 4.00, and the expression of adiA was the highest at $\mathrm{pH}$ 
TABLE 6 | BAs formed by different strains of the same species in single substrate and mixed substrate.

\begin{tabular}{|c|c|c|c|c|}
\hline \multirow{2}{*}{$\begin{array}{l}\text { Strain } \\
\text { number }\end{array}$} & \multirow[t]{2}{*}{ Strains } & \multirow[t]{2}{*}{ BA } & \multicolumn{2}{|c|}{ Biogenic amines content (mg/L) } \\
\hline & & & pH 6.7 (Single) & pH 6.7 (Mix) \\
\hline \multirow[t]{3}{*}{$13 \mathrm{C} 2$} & Klebsiella aerogenes & Put & 900 & 652 \\
\hline & & Cad & 1771 & 246 \\
\hline & & $\mathrm{Him}$ & 1869 & 1601 \\
\hline \multirow[t]{3}{*}{$10 \mathrm{C2}$} & Klebsiella aerogenes & Put & 1339 & 1071 \\
\hline & & Cad & 1751 & 94.6 \\
\hline & & Him & 1723 & 708 \\
\hline \multirow[t]{3}{*}{$35 \mathrm{C3}$} & Morganella morganii & Put & 1254 & 1099 \\
\hline & & Cad & 104 & 109 \\
\hline & & $\mathrm{Him}$ & 941 & 4648 \\
\hline \multirow[t]{3}{*}{$45 \mathrm{C} 2$} & Morganella morganii & Put & 1100 & 1478 \\
\hline & & Cad & 1596 & 100 \\
\hline & & $\mathrm{Him}$ & 1113 & 400 \\
\hline
\end{tabular}

Him, histamine; Put, putrescine; Cad, cadaverine. Single: single substrate. Mix: mix substrates.

4.50 (citric acid buffer) (Álvarez-Ordóñez et al., 2010; Usheer et al., 2011). As shown in Figures 3, 4A, the production of putrescine at $\mathrm{pH} 5.00$ and 4.50 was higher than that at $\mathrm{pH}$
6.00. Our results also demonstrate that the putrescine produced by adding arginine at $\mathrm{pH} 4.50$ (data not shown) was higher than that at $\mathrm{pH} 6.70$ (Figure 2), and the putrescine produced by adding L-ornithine hydrochloride at $\mathrm{pH} 4.50$ (data not shown) was slightly lower than that at $\mathrm{pH}$ 6.70. The $\mathrm{pH}$ seems not to affect odc expression levels but the activity of odc enzymes decreases under acidic conditions (de las Rivas et al., 2008; Usheer et al., 2011). However, at pH 4.50, the total amount of putrescine obtained by adding two types of single substrates was higher than that obtained by mixing substrates (data not shown). The reason might be that other metabolic pathways $(h d c, l d c)$ are also involved in the acid stress response, thus, reducing the formation of putrescine. At $\mathrm{pH}$ 4.50 , which of the two pathways contributes the most in the production of putrescine in the mixed substrates? We need to do in-depth research.

\section{Effect of different $p H$ levels on cadaverine content}

As shown in Figures 3, 4B, pH significantly affected the cadaverine-producing ability of the tested bacteria $(P<0.01)$. As the $\mathrm{pH}$ was decreased from 6.70 to 4.50 , the total cadaverine content increased gradually (Figure 4B). The total cadaverine content of the 27 strains reached the maximum at $\mathrm{pH} 4.50$ and the lowest at $\mathrm{pH} 6.70$ (Figure 3). At $\mathrm{pH} 4.50,25.9 \%$
A

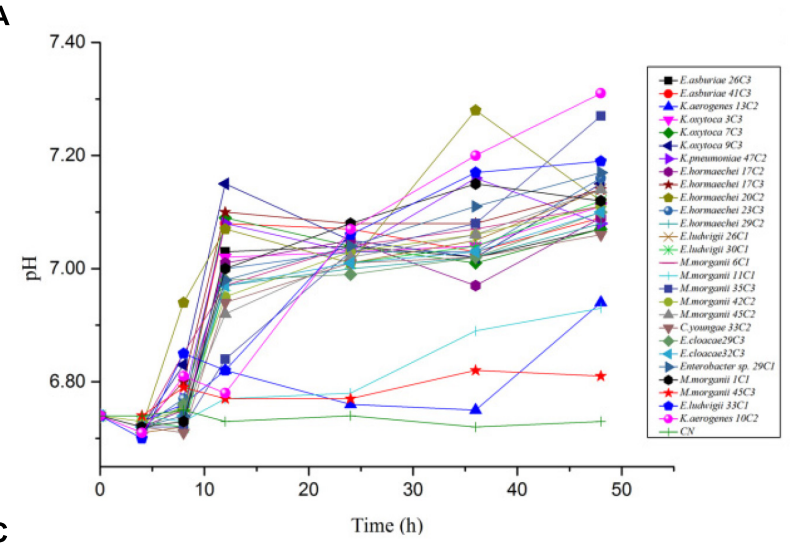

C

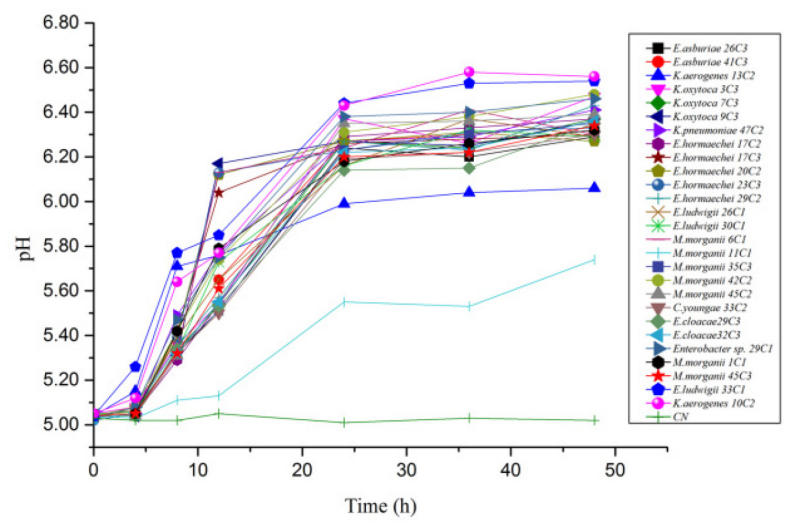

B

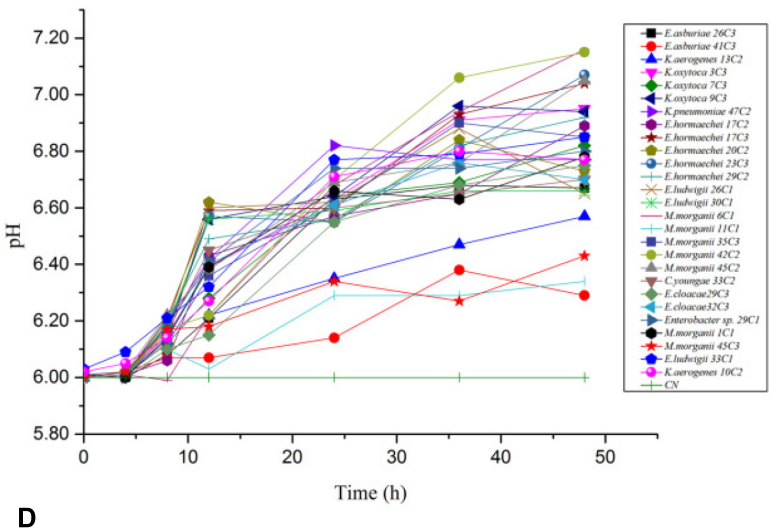

D

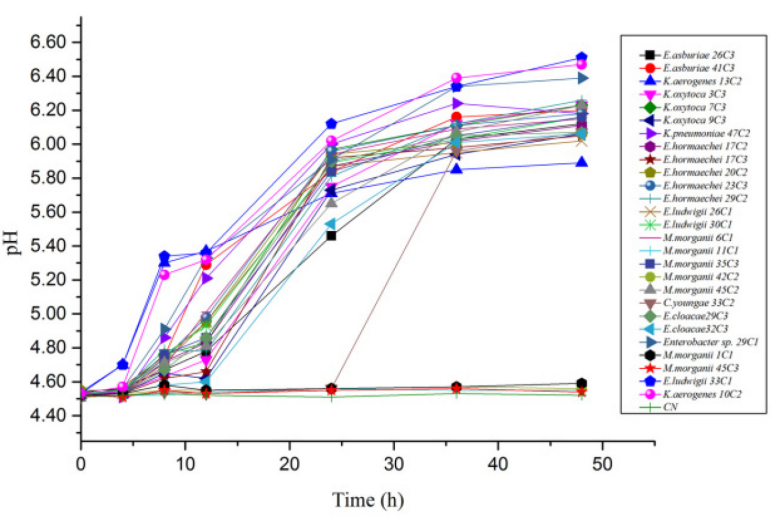

FIGURE 5 | The $\mathrm{pH}$ value change rules of different strains of enteric bacteria under the stresses of different $\mathrm{pH}$ values. (A) $\mathrm{pH}$ 6.70. (B) $\mathrm{pH}$ 6.00. (C) $\mathrm{pH} 5.00$. (D) $\mathrm{pH}$ 4.50 . 

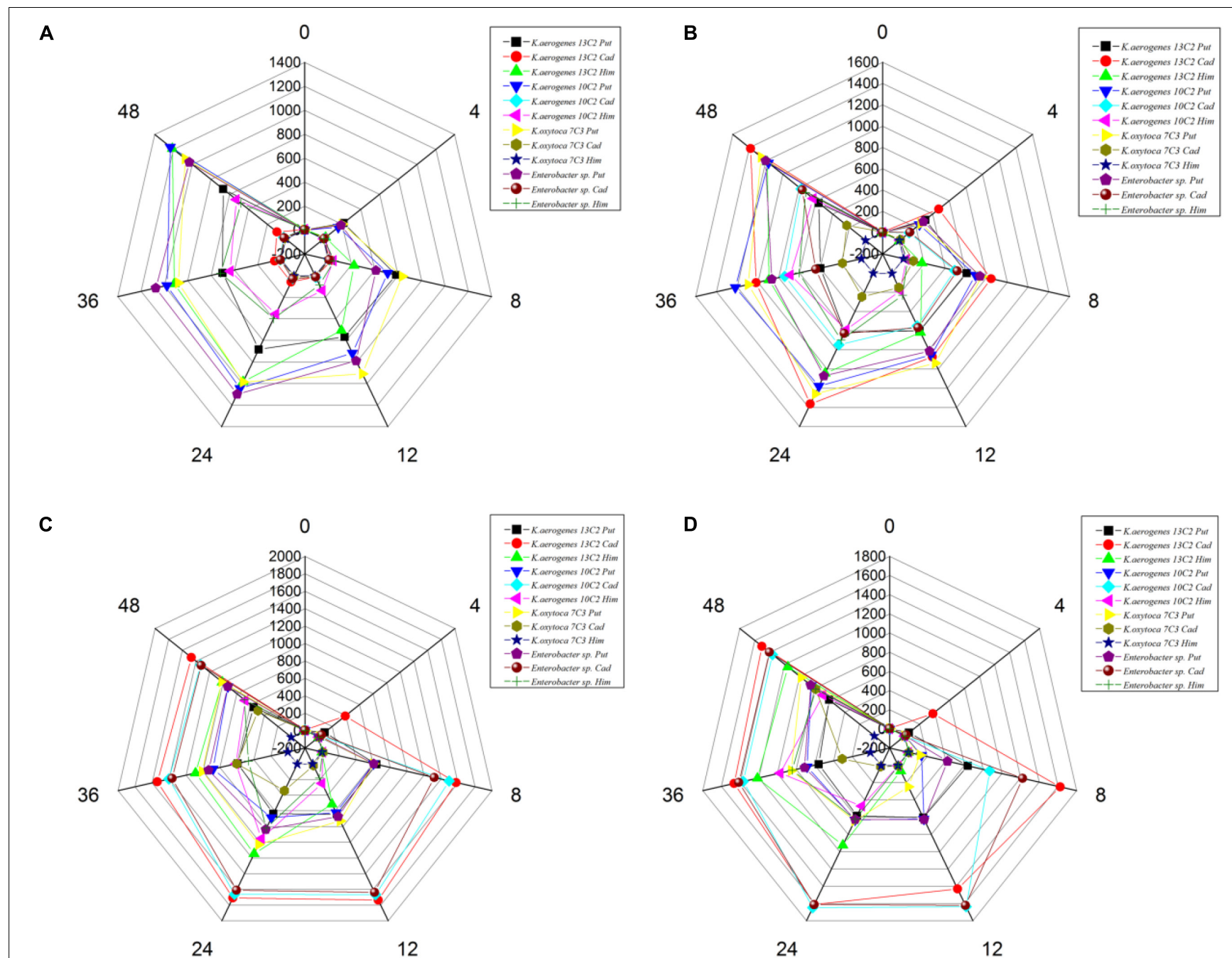

24

12

24

12

FIGURE 6 | The types and content of BAs by different strains of enteric bacteria for 0, 4, 8, 12, 24, 36, 48 h under the stresses of different $\mathrm{pH}$ values. (A) pH 6.70 . (B) $\mathrm{pH}$ 6.00. (C) $\mathrm{pH}$ 5.00. (D) $\mathrm{pH} 4.50$.

(7/27) of the strains produced more than $1,400 \mathrm{mg} / \mathrm{L}$ of cadaverine. The highest cadaverine content was produced by K. aerogenes $13 \mathrm{C} 2(1,862 \mathrm{mg} / \mathrm{L})$, followed by $K$. oxytoca 9C3 (1,813 mg/L), E. asburiae 41C3 (1,793 mg/L), K. pneumoniae 47C2 (1,736 mg/L), Enterobacter sp. 29C1 (1,477 mg/L), and K. aerogenes $10 \mathrm{C} 2(1,453 \mathrm{mg} / \mathrm{L})$ (Figure $4 \mathrm{~B})$. The obtained results were in agreement with the findings of a previous study possibly because abundant $l d c$ expression was induced under acid stress (Bover-Cid et al., 2001; Greif et al., 2006). Some studies have indicated that the $l d c$ expression of E. coli is induced at acidic $\mathrm{pH}$ as well as by high concentrations of the respective amino acids (Park et al., 2017). The optimum $\mathrm{pH}$ level for the decarboxylation activity of Klebsiella and E. coli is 5.50 ( $\mathrm{Li}$ et al., 2014). In addition, Tanaka et al. (2008) indicated that the addition of lysine improves Vibrio parahaemolyticus acid survival, and $l d c$ expression at $\mathrm{pH} 5.00$ is higher than that at $\mathrm{pH} 5.50$, suggesting that ldc plays a role in the adaptive acid tolerance response.
Our findings showed that the optimum $\mathrm{pH}$ for the $l d c$ activity of enteric bacteria was 4.50-5.00 in the medium with mixed amino acid (Figures 3, 4B). Of the strains produced below $33 \mathrm{mg} / \mathrm{L}$ of cadaverine at $\mathrm{pH} 4.50,59.3 \%(16 / 27)$ showed higher production of putrescine or histamine, especially putrescine (Figure 4).

\section{Effect of different $p H$ levels on histamine content}

As shown in Figures 3, 4C, pH had a significant effect on the histamine-producing ability of the tested bacteria $(P<0.05)$. As the $\mathrm{pH}$ decreased from 6.70 to 4.50 , the total histamine amount of the 27 strains reached the maximum at $\mathrm{pH} 6.00$ and the lowest at $\mathrm{pH} 4.50$ (Figure 3). The total amount was similar at $\mathrm{pH} 6.70$ and 5.00 (Figure 4C). At $\mathrm{pH} 6.00$, $40.7 \%(11 / 27)$ of the strains produced more than $500 \mathrm{mg} / \mathrm{L}$ of histamine, and six strains produced more than $900 \mathrm{mg} / \mathrm{L}$ of histamine. High-level histamine was produced by $K$. aerogenes 13C2 (1,465 mg/L), K. aerogenes 10C2 (969 mg/L), Enterobacter 
A

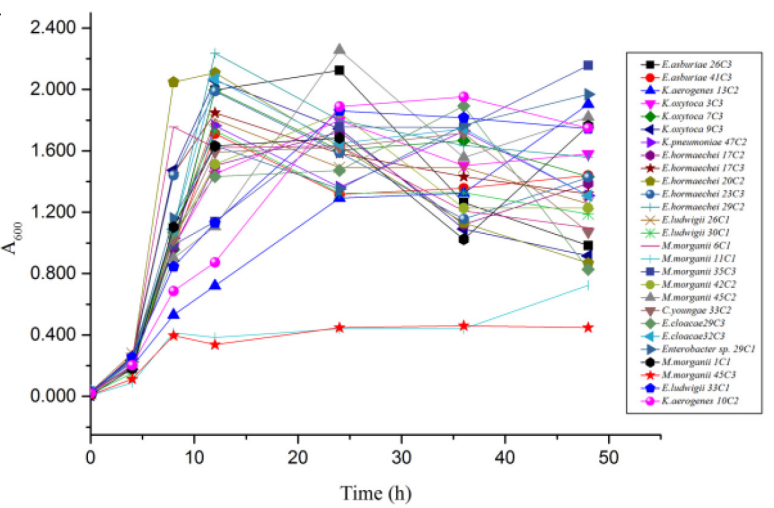

C

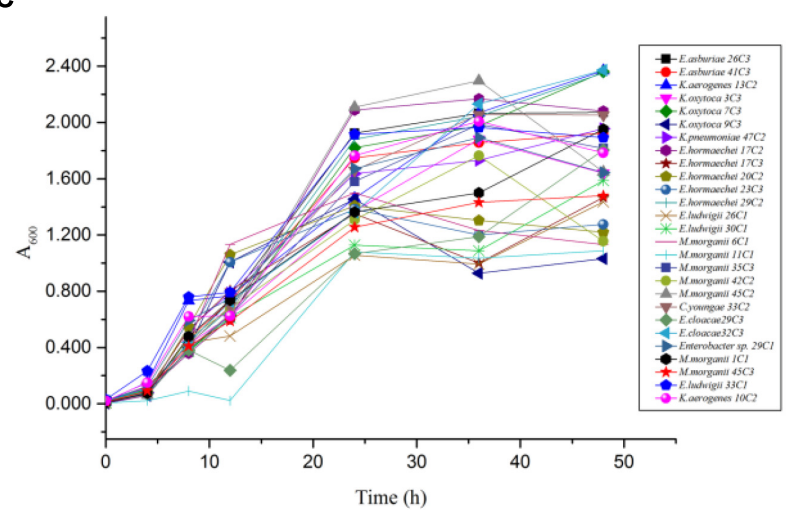

B

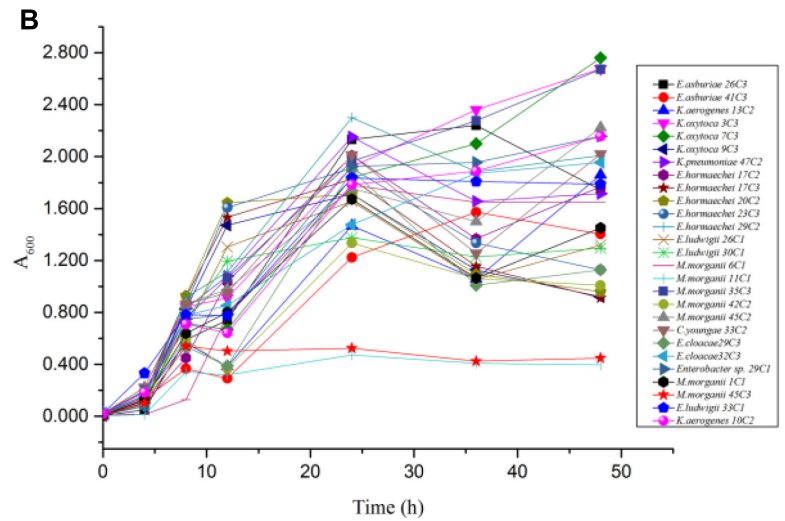

D

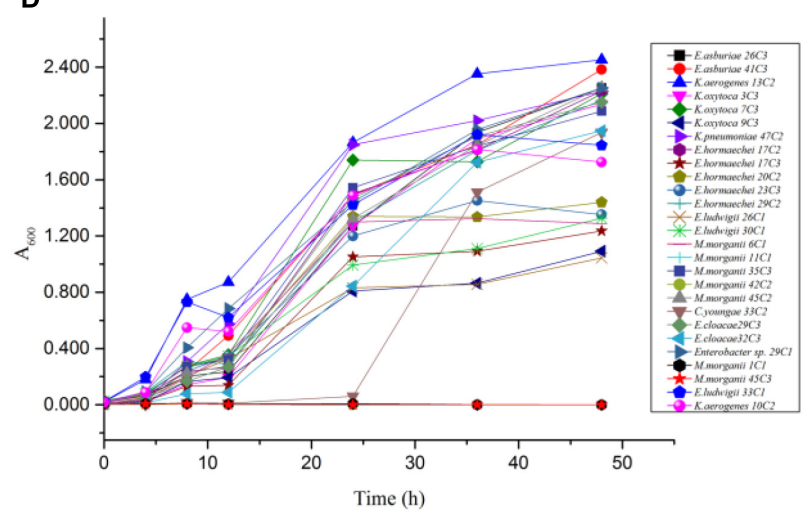

FIGURE 7 | The $\mathrm{OD}_{600}$ value change rules of different strains of enteric bacteria under the stresses of different pH values. (A) pH 6.70. (B) pH 6.00. (C) pH 5.00. (D) $\mathrm{pH} 4.50$.

sp. 29C1 (1,090 mg/L), E. ludwigii 33C1 (1,049 mg/L), M. morganii 45C3 (1,239 $\mathrm{mg} / \mathrm{L})$, and $M$. morganii $11 \mathrm{C} 1$ (905 mg/L) (Figure 4C).

Greif et al. (2006) reported that high amounts of histamine are produced at $\mathrm{pH} 5.80-6.60\left(309-328 \mu \mathrm{g} / \mathrm{cm}^{3}\right)$. Similarly, the optimum $\mathrm{pH}$ for the $h d c$ activity of some bacteria, such as Photobacterium damselae, M. morganii, Raoultella planticola, E. aerogenes, and Proteus vulgaris ranged from 5.00 to 6.50 (Bjornsdottir-Butler et al., 2015). In addition, previous qRT-PCR experiments showed that the $h d c$ and hisRS genes are highly induced under acidic and histidine-rich conditions, and these results support the hypothesis that the $h d c$ pathway in histidine producers plays a role in acid survival (Chiara et al., 2014). According to the above literature, the suitable $\mathrm{pH}$ for histamine production is between 5.00 and 6.60. Our findings showed that the optimum $\mathrm{pH}$ for the $h d c$ activity of enteric bacteria was 5.006.00 in the medium with mixed amino acid (Figures 3, 4C). The obtained results were in agreement with a previous study (Bjornsdottir-Butler et al., 2015; Hu et al., 2015).

\section{Mutual cooperation of different amine production pathways on different $p H$ values}

Interestingly, the content of BAs produced by the same strain under a single amino acid and mixed amino acid enrichment medium was different (Table 6 and Figures 2, 4). For instance, at $\mathrm{pH}$ 6.70, some strains produced particularly high amounts of putrescine, histamine, and cadaverine in a single amino acid enrichment medium, but they produced large amounts of putrescine and less histamine and cadaverine in the mixed amino acid enrichment medium. As the $\mathrm{pH}$ was decreased from 6.70 to 4.50 , the contents of histamine and cadaverine increased, especially cadaverine (Figure 4). Histamine production was the highest when putrescine production was the lowest at pH 6.00 (Figure 3). The total cadaverine content of the 27 strains reached the maximum at $\mathrm{pH} 4.50$ and the lowest at $\mathrm{pH} 6.70$ (Figures 3, 4B). At $\mathrm{pH} 4.50$, the total amount of putrescine obtained by adding two types of single substrates was higher than that obtained by mixing substrates (data not shown). These results indicated that $\mathrm{pH}$ can affect the type and ability of BAs formed by enteric bacteria from Suan yu. This phenomenon may be attributed to the cooperation of various amino acid decarboxylase pathways under acid stress and to the effect of $\mathrm{pH}$ on the activity of amino acid decarboxylase (Table 6 and Figures 2-4).

In the mixed amino acid enrichment medium, excessive production of BAs is unnecessary to balance intracellular and extracellular $\mathrm{pH}$ at $\mathrm{pH}$ 6.70. As the cultivation time was prolonged from 0 to $48 \mathrm{~h}$, the $\mathrm{pH}$ value of the cultures 
reached the peak of growth in $12 \mathrm{~h}$ (Figure 5A). Subsequently, the $\mathrm{pH}$ evolution of the cultures stabilized. The $\mathrm{pH}$ value of the medium changed from 6.70 to 7.31, with a span of $0.10-0.61$. The content of BAs in the culture process of strains $K$. aerogenes 10C2, 13C2, and Enterobacter sp. 29C1 at this $\mathrm{pH}$ was measured. A large amount of putrescine was produced first after $4 \mathrm{~h}$ of cultivation, and the histamine and cadaverine contents were lower than $10 \mathrm{mg} / \mathrm{L}$. The histamine content increased rapidly after $8 \mathrm{~h}$ of cultivation. The content of cadaverine did not change considerably in $48 \mathrm{~h}$ (Figure 6A). The results showed that the production of putrescine and histamine raised the $\mathrm{pH}$ of the broth. The $\mathrm{A}_{600}$ of cell turbidity in the broths with amino acids was measured. At $8 \mathrm{~h}$, the OD600 value reached above 0.6-0.8. At $12 \mathrm{~h}$, it reached the maximum value (except $45 \mathrm{C} 3$ and $11 \mathrm{C} 1)$. Subsequently, it decreased with prolonged culture time but remained above 0.8 (Figure $7 \mathbf{A}$ ). This result indicated that the growth of the strain was normal. However, as the $\mathrm{pH}$ was decreased from 6.7 to 4.5 , more BAs need to be produced to balance the intracellular and extracellular $\mathrm{pH}$, thus increasing the decarboxylation of other amino acids. As shown in Figures $5 \mathbf{B}-\mathbf{D}$, the $\mathrm{pH}$ of the medium under acid stress increased rapidly after $4 \mathrm{~h}$. Meanwhile, the $\mathrm{pH}$ of the broth at $\mathrm{pH} 6.00,5.00$, and 4.50 reached a stable level at 36, 24, and $36 \mathrm{~h}$, respectively. The change spans of the $\mathrm{pH}$ value were $0.29-1.16,0.74-1.56$, and $0.04-2.01$, respectively (Figures 5BD). Figure 6B shows that the contents of putrescine and cadaverine increased for $4 \mathrm{~h}$, and the content of histamine increased gradually after $4 \mathrm{~h}$ in the $\mathrm{pH} 6.00$ medium. In the $\mathrm{pH} 5.00$ and 4.50 media (Figures 6C,D), a large amount of cadaverine was produced after $4 \mathrm{~h}$ of cultivation, followed by putrescine. After $12 \mathrm{~h}$ of cultivation, the histamine content increased rapidly. The $\mathrm{pH} 5.00$ medium can quickly reach $\mathrm{pH}$ stability because the $\mathrm{pH}$ was the optimal $\mathrm{pH}$ for adiA and $l d c$. When the optimal $\mathrm{pH}$ for $h d c$ was reached, the histamine production pathway participated in the $\mathrm{pH}$ adjustment. The above results illustrate that different BA production pathways work together to improve the extracellular $\mathrm{pH}$. The OD600 values of the $\mathrm{pH} 6.00,5.00$, and 4.50 broths reached 0.60.8 at 10,12 , and $20 \mathrm{~h}$ (Figures $7 \mathbf{B}-\mathbf{D}$ ), respectively, which were delayed for 2, 4, and $12 \mathrm{~h}$, respectively, compared with that of the $\mathrm{pH} 6.7$ broth (Figure 7A). In addition, the OD600 values reached the growth peak at 24, 36, and $48 \mathrm{~h}$, respectively, which were delayed for 12,24 , and $36 \mathrm{~h}$ (Figures 7B-D), respectively, compared with pH 6.7 (Figure 7A). As shown in Figures 3, 6, 7, acid stress caused the growth delay, which did not affect the production of putrescine, cadaverine, and histamine contents; on the contrary, acid stress can increase the contents of these BAs. $K$. oxytoca 7C3 does not carry the $h d c$ gene and does not produce histamine. A large amount of putrescine was produced from $\mathrm{pH}$ 6.70-4.50, and part of cadaverine was used to adjust the acid environment. Nevertheless, it produced particularly high amounts of cadaverine in a single substrate.

The above-mentioned results indicated that $\mathrm{pH}$ can considerably affect the BA-producing ability of the tested bacteria. odc, adiA, speB, $l d c$, and $h d c$ were important for enteric bacteria survival under acidic conditions, and these pathways should be collaborative. At $\mathrm{pH} 6.70$ and 6.00 , the putrescine, histamine, and cadaverine production dominated in the regulation of extracellular acid environment in most strains of enteric bacteria. At pH 5.00 and 4.50, the putrescine and cadaverine production in the regulation of extracellular acid environment in most strains of enteric bacteria and the putrescine and histamine production are the main pathways in a few enteric bacteria. Decarboxylase was strain specific rather than species specific $(P<0.01)$ (Table 6 and Figures 2-4, 6).

\section{CONCLUSION}

Out of 97 strains showing high BA levels, 88, 47, and 16 strains produced more than $100 \mathrm{mg} / \mathrm{L}$ of putrescine, histamine, and cadaverine, respectively. All tested strains carried the corresponding amino acid decarboxylase genes of putrescine (odc, speA, speB, and $a d i A$ ) and cadaverine $(l d c)$. In addition, 13 of 27 strains carried histidine decarboxylase gene $(h d c)$. odc, adiA, speB, ldc, and $h d c$ were important for enteric bacteria survival under acidic conditions, and these pathways should be collaborative. Decarboxylase was strain specific rather than species specific $(P<0.01)$. Our results indicated that acid stress caused the growth delay but can increase the contents of putrescine, histamine, and cadaverine. On the one hand, this study can provide a reference for the genotypic diversity of decarboxylase of BAproducing bacteria and the effect of $\mathrm{pH}$ on the types and abilities of BAs produced by enteric bacteria in proteinrich fermented fish. On the other hand, fermented lowacid and high-protein foods must strictly prevent intestinal bacterial contamination; otherwise, large amounts of BAs will be generated. Unqualified products will cause economic loss and safety hazards.

\section{DATA AVAILABILITY STATEMENT}

The raw data supporting the conclusions of this article will be made available by the authors, without undue reservation, to any qualified researcher.

\section{ETHICS STATEMENT}

Ethical review and approval was not required for the animal study because Suan yu is a local snack that has been consumed for a long time by ethnic minority people in southwest China.

\section{AUTHOR CONTRIBUTIONS}

QY wrote the main manuscript text. JM and LL prepared Figures 1-3 and Tables 1-6. WZ prepared Figures 5-7 and modified the manuscript. LH, LD, and CY provided advice for the manuscript. XZ directed and modified the manuscript. 


\section{FUNDING}

This research was financially supported by the Natural Science Foundation of China 31760455, Key Project in Agricultural of Guizhou Province in [2016]2579,

\section{REFERENCES}

Álvarez-Ordóñez, A., Fernández, A., Bernardo, A., and López, M. (2010). Arginine and lysine decarboxylases and the acid tolerance response of Salmonella typhimurium. Int. J. Food Microbiol. 136, 278-282. doi: 10.1016/j.ijfoodmicro. 2009.09.024

Ben-Gigirey, B., Vieites Baptista de Sousa, J. M., and Villa, T. G. (1998). Changes in biogenic amines and microbiological analysis in albacore (Thunnus alalunga) muscle during frozen storage. J. Food Protect. 61, 608-615. doi: 10.4315/0362028x-61.5.608

Bjornsdottir, K., Bolton, G. E., Mcclellangreen, P. D., Jaykus, L. A., and Green, D. P. (2009). Detection of gram-negative histamine-producing bacteria in fish: a comparative study. J. Food Protect. 72, 1987-1991. doi: 10.4315/0362-028x72.9.1987

Bjornsdottir-Butler, K., Bolton, G. E., Jaykus, L. A., McClellan-Green, P. D., and Green, D. P. (2010). Development of molecular-based methods for determination of high histamine producing bacteria in fish. Int. J. Food Microbiol. 139, 161-167. doi: 10.1016/j.ijfoodmicro.2010.03.017

Bjornsdottir-Butler, K., Green, D. P., Bolton, G. E., and McClellan-Green, P. D. (2015). Control of histamine-producing bacteria and histamine formation in fish muscle by trisodium phosphate. J. Food Sci. 80, 1253-1258.

Bover-Cid, S., Hugas, M., Izquierdo-Pulido, M., and Vidal-Carou, M. C. (2001). Amino acid-decarboxylase activity of bacteria isolated from fermented pork sausages. Int. J. Food Microbiol. 66, 185-189. doi: 10.1016/s0168-1605(00) 00526- 2

Bover-Cid, S., Latorre-Moratalla, M. L., Veciana-Nogués, M. T., and Vidal-Carou, M. C. (2014). Processing contaminants: biogenic amines. Encyclopedia Food Saf. 2, 381-391. doi: 10.1016/b978-0-12-378612-8.00216-x

Chen, H.-C., Huang, Y.-R., Hsu, H.-H., Lin, C.-S., Chen, W.-C., Lin, C.M., et al. (2010). Determination of histamine and biogenic amines in fish cubes (Tetrapturus angustirostris) implicated in a food-borne poisoning. Food Control 21, 13-18. doi: 10.1016/j.foodcont.2009.03.014

Chiara, F., Francesca, B., Blanca, D. L. R., Rosario, M. O., Giovanni, R., and Maria Grazia, F. (2014). Sequencing, characterization, and gene expression analysis of the histidine decarboxylase gene cluster of Morganella morganii. Curr. Microbiol. 68, 404-411. doi: 10.1007/s00284-013-0490-7

Coton, M., Romano, A., Spano, G., Ziegler, K., Vetrana, C., Desmarais, C., et al. (2010). Occurrence of biogenic amine-forming lactic acid bacteria in wine and cider. Food Microbiol. 27, 1078-1085. doi: 10.1016/j.fm.2010.07.012

Curiel, J. A., RuizCapillas, C., Rivas, B. D. L., Carrascosa, A. V., Jiménez Colmenero, F., and Muñoz, R. (2011). Production of biogenic amines by lactic acid bacteria and Enterobacteria isolated from fresh pork sausages packaged in different atmospheres and kept under refrigeration. Meat Sci. 88, 368-373. doi: 10.1016/j.meatsci.2011.01.011

de las Rivas, B., González García, R., Landete, J. M., and Muñoz, R. (2008). Characterization of a second ornithine decarboxylase isolated from Morganella morganii. J. Food Protect. 71, 657-661. doi: 10.4315/0362-028x-71.3.657

de las Rivas, B., Marcobal, A., Carrascosa, A. V., and Muñoz, R. (2006). PCR detection of foodborne bacteria producing the biogenic amines histamine, tyramine, putrescine, and cadaverine. J. Food Protect. 69, 2509-2514. doi: 10.4315/0362-028x-69.10.2509

de las Rivas, B., Marcobal, A., and Muñoz, R. (2005). Improved multiplex-PCR method for the simultaneous detection of food bacteria producing biogenic amines. FEMS Microbiol. Lett. 244, 367-372. doi: 10.1016/j.femsle.2005. 02.012

Doeun, D., Davaatseren, M., and Chung, M. S. (2017). Biogenic amines in foods. Food Sci. Biotechnol. 26, 1463-1474.

Gardini, F., Özogul, Y., Suzzi, G., Tabanelli, G., and Özogul, F. (2016). Technological factors affecting biogenic amine content in foods: a review. Front. Microbiol. 7:1218. doi: 10.3389/fmicb.2016.01218
Guizhou Provincial Natural Science Foundation of China [2016]1046, the National Key R\&D Program of China (No. 2018YFD0401200), and Construction Program of Biology First-class Discipline in Guizhou (GNYL [2017] 009).

Gassem, M. A. (2017). Microbiological and chemical quality of a traditional saltedfermented fish (Hout-Kasef) product of jazan region, Saudi Arabia. Saudi J. Biol. Sci. 26, 137-140. doi: 10.1016/j.sjbs.2017.04.003

Greif, G., Greifová, M., and Karovièová, J. (2006). Effects of $\mathrm{NaCl}$ concentration and initial $\mathrm{pH}$ value on biogenic amine formation dynamics by Enterobacter spp. bacteria in model conditions. J. Food Nutr. Res. 45, 21-29.

Hsu, H. H., Chuang, T. C., Lin, H. C., Huang, Y. R., Lin, C. M., Kung, H. F., et al. (2009). Histamine content and histamine-forming bacteria in dried milkfish (Chanos chanos) products. Food Chem. 114, 933-938. doi: 10.1016/j.foodchem. 2008.10.040

Hu, J.-W., Cao, M.-J., Guo, S.-C., Zhang, L.-J., Su, W.-J., and Liu, G.-M. (2015). Identification and inhibition of histamine-forming bacteria in blue scad (Decapterus maruadsi) and chub mackerel (Scomber japonicus). J. Food Protect. 78, 383-389. doi: 10.4315/0362-028x.jfp-14-296

Ishimaru, M., Muto, Y., Nakayama, A., Hatate, H., and Tanaka, R. (2019). Determination of biogenic amines in fish meat and fermented foods using column-switching high-performance liquid chromatography with fluorescence detection. Food Anal. Methods 12, 166-175. doi: 10.1007/s12161-018-1349-0

Kanjee, U., Gutsche, I., Ramachandran, S., and Houry, W. A. (2011). The enzymatic activities of the Escherichia coli basic aliphatic amino acid decarboxylases exhibit a pH zone of inhibition. Biochemistry 50, 9388-9398. doi: 10.1021/bi201161k

Kim, M. K., Mah, J.-H., and Hwang, H.-J. (2009). Biogenic amine formation and bacterial contribution in fish, squid and shellfish. Food Chem. 116, 87-95. doi: 10.1016/j.foodchem.2009.02.010

Ladero, V., Fernández, M., Calles-Enríquez, M., Sánchez-Llana, E., Cañedo, E., Martín, M. C., et al. (2012). Is the production of the biogenic amines tyramine and putrescine a species-level trait in enterococci? Food Microbiol. 30, 132-138. doi: 10.1016/j.fm.2011.12.016

Landete, J. M., Rivas, B. D. L., Marcobal, A., and Muñoz, R. (2011). PCR methods for the detection of biogenic amine-producing bacteria on wine. Ann. Microbiol. 61, 159-166. doi: 10.1007/s13213-010-0068-6

Latorremoratalla, M. L., Bovercid, S., Boschfusté, J., Veciananogués, M. T., and Vidalcarou, M. C. (2014). Amino acid availability as an influential factor on the biogenic amine formation in dry fermented sausages. Food Control 36, 76-81. doi: 10.1016/j.foodcont.2013.07.038

Li, N., Chou, H., Yu, L., and Xu, Y. (2014). Cadaverine production by heterologous expression of Klebsiella oxytoca lysine decarboxylase. Biotechnol. Bioprocess Eng. 19, 965-972. doi: 10.1007/s12257-014-0352-6

Lu, S. L., Jiang, C. H., Xu, X. L., Xu, C. J., Li, K. X., and Shu, R. H. (2015). Improved screening procedure for biogenic amine production by lactic acid bacteria and Enterobacteria. Czech J. Food Sci. 33, 19-26. doi: 10.17221/197/2014-cjfs

Møller, V. (1954). Distribution of amino acid decarboxlases in Enterobacteriaceae. Acta Pathol. Microbiol. Scand. 35, 259-277.

Naila, A., Flint, S., Fletcher, G. C., Bremer, P. J., and Meerdink, G. (2011). Biogenic amines and potential histamine - forming bacteria in Rihaakuru (a cooked fish paste). Food Chem. 128, 479-484. doi: 10.1016/j.foodchem.2011.03.057

Ozogul, F., Kacar, Ç, and Hamed, I. (2015). Inhibition effects of carvacrol on biogenic amines formation by common food-borne pathogens in histidine decarboxylase broth. LWT Food Sci. Technol. 64, 50-55. doi: 10.1016/j.lwt.2015. 05.027

Park, S. H., Soetyono, F., and Kim, H. K. (2017). Cadaverine production by using cross-linked enzyme aggregate of Escherichia coli lysine decarboxylase. J. Microbiol. Biotechnol. 27, 289-296. doi: 10.4014/jmb.1608.08033

Rio, B. D., Linares, D., Ladero, V., Redruello, B., Fernandez, M., Martin, M. C., et al. (2016). Putrescine biosynthesis in Lactococcus lactis is transcriptionally activated at acidic $\mathrm{pH}$ and counteracts acidification of the cytosol. Int. J. Food Microbiol. 236, 83-89. doi: 10.1016/j.ijfoodmicro.2016.07.021

Takahashi, H., Ogai, M., Miya, S., Kuda, T., and Kimura, B. (2015). Effects of environmental factors on histamine production in the psychrophilic 
histamine-producing bacterium Photobacterium iliopiscarium. Food Control 52, 39-42. doi: 10.1016/j.foodcont.2014.12.023

Tanaka, Y., Kimura, B., Takahashi, H., Watanabe, T., and Fujii, T. (2008). Lysine decarboxylase of Vibrio parahaemolyticus: kinetics of transcription and role in acid resistance. J. Appl. Microbiol. 104, 1283-1293. doi: 10.1111/j.1365-2672. 2007.03652.x

Tittarelli, F., Perpetuini, G., Di Gianvito, P., and Tofalo, R. (2019). Biogenic amines producing and degrading bacteria: a snapshot from raw ewes' cheese. LWT Food Sci. Technol. 101, 1-9. doi: 10.1016/j.lwt.2018.11.030

Tofalo, R., Perpetuini, G., Schirone, M., and Suzzi, G. (2016). "Biogenic amines: toxicology and health effect," in The Encyclopedia of Food and Health. 1, eds B. Caballero, P. Finglas, and F. Toldrá (Oxford: Academic Press).

Torido, Y., Ohshima, C., Takahashi, H., Miya, S., Ai, I., Kuda, T., et al. (2014). Distribution of psychrophilic and mesophilic histamine-producing bacteria in retailed fish in Japan. Food Control 46, 338-342. doi: 10.1016/j.foodcont.2014. 05.045

Torido, Y., Takahashi, H., Kuda, T., and Kimura, B. (2012). Analysis of the growth of histamine-producing bacteria and histamine accumulation in fish during storage at low temperatures. Food Control 26, 174-177. doi: 10.1016/j.foodcont. 2012.01.009

Usheer, K., Irina, G., Shaliny, R., and Houry, W. A. (2011). The enzymatic activities of the Escherichia coli basic aliphatic amino acid decarboxylases exhibit a pH zone of inhibition. Biochemistry 50, 9388-9398. doi: 10.1021/bi201 $161 \mathrm{k}$

Wunderlichová, L., Buòková, L., Koutn $\iota$, M., Janèová, P., and Buòka, F. (2015). Formation, degradation, and detoxification of putrescine by foodborne bacteria: a review. Comprehensive Rev. Food Sci. Food Saf. 13, 1012-1030. doi: 10.1111/ 1541-4337.12099
Wunderlichová, L., Buòková, L., Koutnı, M., Valenta, T., and Buòka, F. (2013). Novel touchdown-PCR method for the detection of putrescine producing Gram-negative bacteria in food products. Food Microbiol. 34, 268-276. doi: 10.1016/j.fm.2012.09.024

Xu, Y., He, L., Xia, W., Jiang, Q., and Wang, B. (2019). The impact of fermentation at elevated temperature on quality attributes and biogenic amines formation of low salt fermented fish. Int. J. Food Sci. Technol. 54, 723-733. doi: 10.1111/ijfs. 13986

Zeng, X., Xia, W., Fang, Y., and Jiang, Q. (2013a). Changes of biogenic amines in Chinese low-salt fermented fish pieces (Suan yu) inoculated with mixed starter cultures. Int. J. Food Sci. Technol. 48, 685-692. doi: 10.1111/ijfs.12010

Zeng, X., Xia, W., Jiang, Q., and Fang, Y. (2013b). Chemical and microbial properties of Chinese traditional low-salt;fermented whole fish product Suan yu. Food Control 30, 590-595. doi: 10.1016/j.foodcont.2012.07.037

Zhai, H., Yang, X., Li, L., Xia, G., Cen, J., Hui, H., et al. (2012). Biogenic amines in commercial fish and fish products sold in southern China. Food Control 25, 303-308. doi: 10.1016/j.foodcont.2011.10.057

Conflict of Interest: The authors declare that the research was conducted in the absence of any commercial or financial relationships that could be construed as a potential conflict of interest.

Copyright (c) 2020 Yang, Meng, Zhang, Liu, He, Deng, Zeng and Ye. This is an open-access article distributed under the terms of the Creative Commons Attribution License (CC BY). The use, distribution or reproduction in other forums is permitted, provided the original author(s) and the copyright owner(s) are credited and that the original publication in this journal is cited, in accordance with accepted academic practice. No use, distribution or reproduction is permitted which does not comply with these terms. 